\title{
Characterization of $\mathrm{ZrO}_{2}$ Buffer Layers for Sequentially Evaporated $\mathrm{Y}$-Ba-Cu-O on $\mathrm{Si}$ and $\mathrm{Al}_{2} \mathrm{O}_{3}$ Substrates
}

George J. Valco and Norman J. Rohrer

The Ohio State University

Columbus, Ohio

and

John J. Pouch, Joseph D. Warner, and Kul B. Bhasin

Lewis Research Center

Cleveland, Ohio

Prepared for the

Conference on the Science and Technology of Thin Film Superconductors cosponsored by the U.S. Department of Energy, Solar Energy Research Institute, National Bureau of Standards, Naval Research Laboratory, and Lawrence Berkeley Laboratory

Colorado Springs, Colorado, November 14-18, 1988

\section{N/SA}

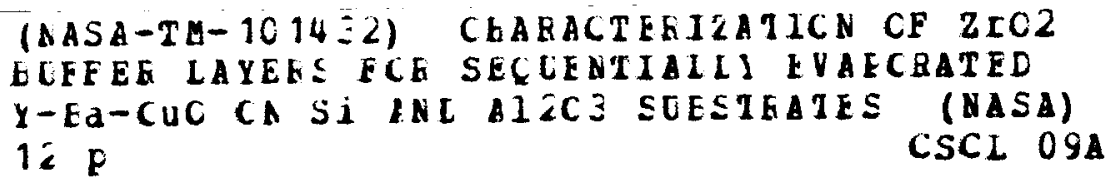


CHARACTERIZATION OF $\mathrm{ZrO}_{2}$ BUFFER LAYERS FOR SEQUENTIALLY

EVAPORATED Y-Ba-CU-O ON Si AND $\mathrm{Al}_{2} \mathrm{O}_{3}$ SUBSTRATES

George J. Valco and Norman J. Rohrer

Department of Electrical Engineering

The Ohio State University

Columbus, Ohio 43210

and

John J. Pouch, Joseph D. Warner, and Kul B. Bhasin

National Aeronautics and Space Administration

Lewis Research Center

Cleveland, Ohio 44135

INIRODUCTION

A large variety of techniques have been employed for the formation of thin films of the high temperature superconducting oxides on many different substrates. These efforts have been driven by the desire to investigate and develop electronic applications of these materials. Several of the substrates that have been used possess undesirable electronic properties, such as the large dielectric constant of $\mathrm{SrTiO}_{3}$. For many applications it is desirable to obtain the superconducting łilms on silicon or, for high frequency applications, on substrates such as $\mathrm{Al}_{2} \mathrm{O}_{3}$ or GaAs. Unfortunate1y, the deleterious interactions between the films and these substrates or common dielectrics ${ }^{1}$, such as silicon dioxide, result in unacceptable degradation of both the superconductor and the substrate. This has led to the investigation of the use of thin films of materials such as $\mathrm{ZrO}_{2}{ }^{2}$ or silver ${ }^{3}$ as buffer layers between the superconductor and the substrate.

One of the techniques being employed to form thin films of high temperature superconductor involves the sequential evaporation of a multilayer stack containing the constituents of the superconductor followed by annealing in oxygen. When performed by electron beam evaporation from a multi-hearth gun, this technique allows deposition of films with little spatial variation of the stoichiometry as all components of the film are evaporated from the same point in space. In addition, by controlling the thickness of the individually deposited layers, the stoichiometry of the film is easily adjusted. Films have been formed from a variety of starting materials in different combinations using this technique. These include $Y$, $\mathrm{Ba}$ and $\mathrm{Cu}$ metals ${ }^{3} 4,5$, a combination of the metals and their oxides ${ }^{5-7}$, a combination of metals and $\mathrm{BaF}_{2}{ }^{2,8}$ and a combination of oxides and $\mathrm{BaF}_{2}{ }^{9}$.

We have performed sequential evaporation of $\mathrm{Cu}, \mathrm{Y}$ and $\mathrm{BaF}_{2}$ to study the formation of superconducting films on SrTiO, Mgo, yttrium stabilized $\mathrm{ZrO}_{2}$ (YSZ), Si and sapphire substrates. For the silicon and sapphire substrates, we have used a thin film of $\mathrm{ZrO}_{2}$ as a buffer layer. In addition, Auger electron spectroscopy (AES) with argon ion sputtering has been 
utilized to obtain depth profiles through the films and to study the interfacial interactions, particularly on silicon and sapphire substrates. A variety of thicknesses, compositions and annealing conditions have been used to form superconducting films and to prepare samples for the AES analysis. The results of these characterizations are presented here.

\section{SAMPLE PREPARATION}

Sample preparation involved deposition of the $\mathrm{ZrO}_{2}$ buffer layer on those substrates which needed one followed by deposition of the multilayered stack of the constituent elements. The multi ' ayer film was then converted into the YBaCuO compound through a multiple step annealing sequence. To allow electrical characterization, silver contacts were evaporated and heat treated. The details of each of these procedures follow.

Deposition of Films

Deposition of the $\mathrm{Cu}, \mathrm{Y}$ and $\mathrm{BaF}_{2}$ films was performed in a CHA Industries electron beam evaporator. The system is equipped with a four hearth gun, allowing deposition of the multi-layer stack without breaking vacuum. Thickness of the layers was controlled via an Inficon XTC thickness monitor and rate controller. The depositions were calibrated by measurements of step heights using a surface profilometer.

$\mathrm{ZrO}_{2}$ for the buffer layers on the silicon and sapphire substrates was also performed in this evaporator. Samples were prepared with $0.2 \mu \mathrm{m}$ and $0.9 \mu \mathrm{m}$ thick buffer layers.

A cross sectional drawing of the structure of a typical as deposited film with buffer layer is shown on the left side of Figure 1 . For a typical film, after deposition of the buffer layer, approximately $510 \AA$ of copper was deposited on the substrate. This was followed by an approximately $480 \AA$ thick layer of yttrium which was followed by an approximately $1710 \mathrm{~A}$ thick layer of barium fluoride. Thicknesses of the layers were adjusted to vary the composition. For most of our depositions, this multilayered sequence was repeated four times for a total of twelve layers. For the thicknesses listed above, the film is characterized by a barium/yttrium atomic ratio of 1.98 and a copper/yttrium atomic ratio of 2.98 . We have investigated the properties of films with barium/yttrium ratios ranging from 1.9 to 2.4 and copper/yttrium ratios ranging from 2.9 to 3.3 on most substrates and a larger range on $\mathrm{SrTiO}_{3}$. We have used barium fluoride rather than elemental barium since barium fluoride is less reactive.

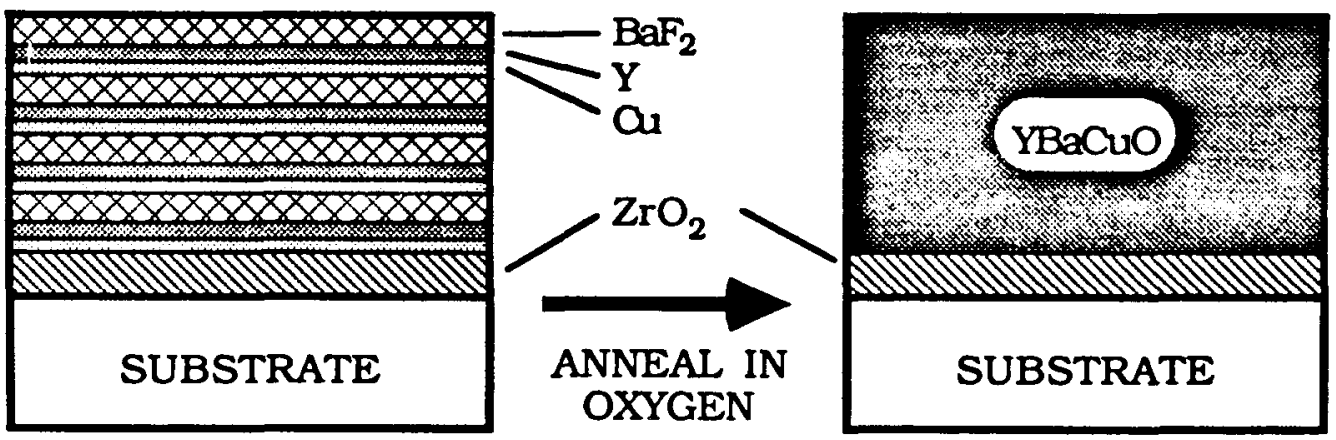

Fig. 1. On the left: Typical twelve layer structure of the as deposited film with $\mathrm{ZrO}_{2}$ buffer layer. On the right: $\mathrm{YBa}_{2} \mathrm{Cu}_{3} \mathrm{O}_{7-6}$ formed after annealing in oxygen. 
The deposited films were annealed in a hot wall, programable, quartz tube furnace. The furnace was preheated to the annealing temperature and purged with oxygen prior to inserting the samples. Temperatures ranged from $850^{\circ} \mathrm{C}$ to $900^{\circ} \mathrm{C}$. The samples were usually pushed into the furnace with a slow $5 \mathrm{~min}$ push. The duration of the anneals ranged from $15 \mathrm{~min}$ to $3 \mathrm{hr}$. The temperature was then ramped to $450^{\circ} \mathrm{C}$ at a rate of $-2^{\circ} \mathrm{C} / \mathrm{min}$. The samples were held at $450^{\circ} \mathrm{C}$ for $6 \mathrm{hr}$ and then the temperature was ramped to room temperature at $-1{ }^{\circ} \mathrm{C} / \mathrm{min}$. During the high temperature portion of the anneal the ambient consisted of ultra high purity oxygen bubbled through room temperature water to assist in removal of fluorine frot tus films. Dry oxygen was used during all other portions of the annealing process.

\section{Electrical Contacts}

Ohmic contacts were formed on the films to allow measurement of their resistance as a function of temperature. Most of the samples were rectangular in shape with widths of approximately $5 \mathrm{~mm}$ and lengths of approximately $1 \mathrm{~cm}$. The contacts for these samples were deposited by evaporation of $1 \mathrm{\mu m}$ of silver through shadow masks to produce four stripes across the width of the samples. For some irregularly shaped samples, shadow masks which produced four dots were used. The contacts were annealed in dry oxygen at $500^{\circ} \mathrm{C}$ for $1 \mathrm{hr}$. They were placed in the tube furnace at room temperature and the temperature was ramped up at $20^{\circ} \mathrm{c} / \mathrm{min}$. At the end of the anneal the temperature was ramped to $250^{\circ} \mathrm{C}$ at a rate of $-2^{\circ} \mathrm{C} / \mathrm{min}$ and then to room temperature at $-1^{\circ} \mathrm{C} / \mathrm{min}$.

\section{CHARACTERIZATION}

To allow measurement of the resistance of the films as a function of temperature, the samples were cooled in a closed cycle helium refrigerator. The samples were mounted onto a sample holder and gold ribbon bonds were made between the silver contacts and bonding posts. A four probe DC measurement was employed to determine the resistance. Measurements were usually started at room temperature and proceeded as the sample was cooled. A few samples were measured both while cooling and while heating, with the same results in both directions. Measurements were continued to well below the transition temperature for superconducting films or to approximately 10K for non-superconducting films.

Auger electron spectroscopy with argon ion sputtering was used to study the $\mathrm{Y}-\mathrm{Ba}-\mathrm{Cu}-\mathrm{O} \mathrm{film}$ and the film/substrate interface. Excitation was obtained through a primary electron beam of $3 \mathrm{keV}$ energy. Sputtering for the depth profiles was performed with a $3 \mathrm{keV}$ argon ion beam. In addition, scanning electron microscopy (SEM) was utilized to observe the morphology of the films.

\section{RESULTS}

Figure 2 shows an AES depth profile through a Y-Ba-Cu-O film on silicon with a $0.9 \mu \mathrm{m}$ thick $\mathrm{ZrO}_{2}$ buffer layer. The film was deposited in twelve layers and was approximately $1.2 \mathrm{\mu m}$ thick prior to annealing. The sample was annealed at $850^{\circ} \mathrm{C}$ for $180 \mathrm{~min}$. The film was dark grey in appearance and scanning electron microscopy showed it to be polycrystalline with randomly oriented grains. From the Auger profile, the superconducting film is seen to be quite uniform throughout its thickness, with no evidence of its multi-layer origin. The film is also free of fluorine to the limits of detection by AES. The interface between the film and the buffer layer, 


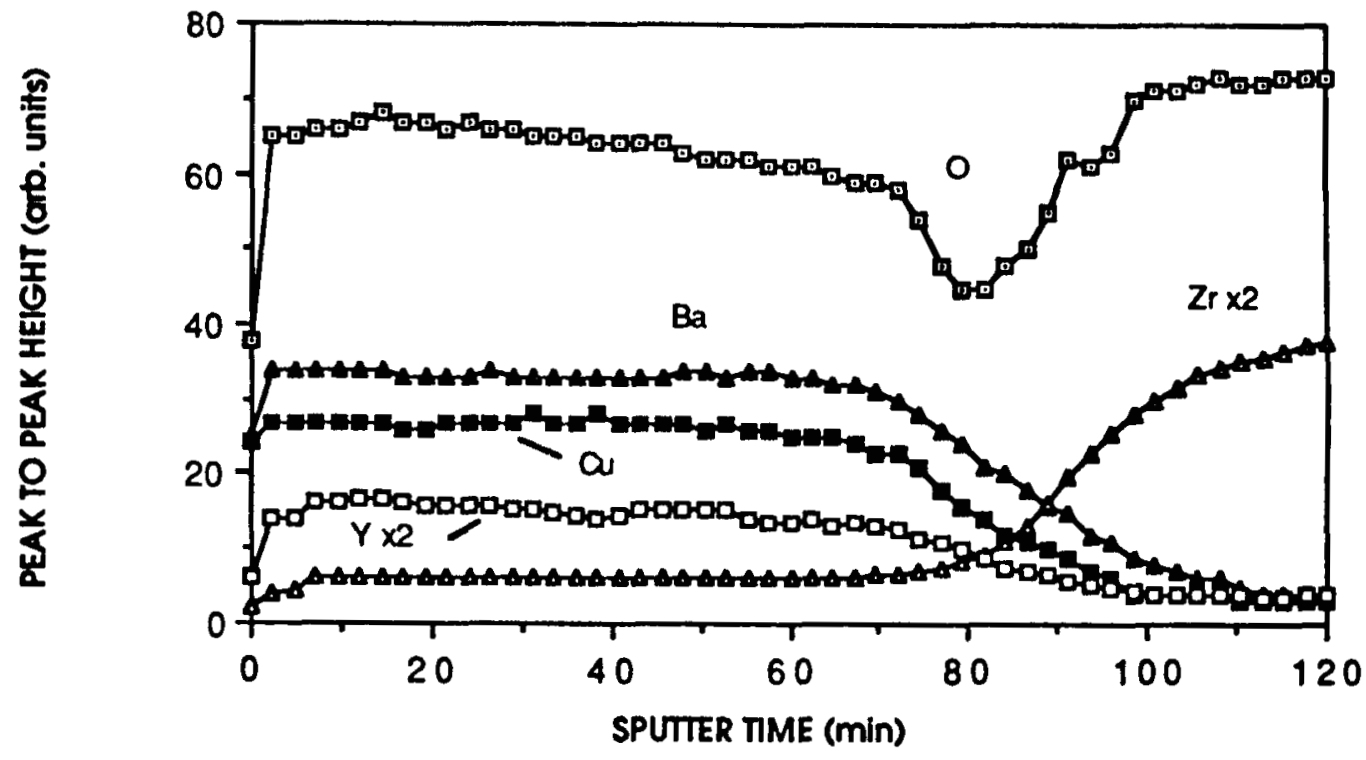

Figure 2: Auger depth profile through a Y-Ba-Cu-O film on silicon with a $0.9 \mu \mathrm{m}$ buffer layer.

although quite broad, is well defined. The profile was stopped before sputtering through the $\mathrm{ZrO}_{2}$ layer but after the $\mathrm{Y}, \mathrm{Ba}$ and $\mathrm{Cu}$ signals had fallen to the background signal level. A survey spectrum was then obtained, to check for the presence of silicon from the substrate in the buffer layer. None was observed.

The width of the interface is probably a result of the long anneal at $850^{\circ} \mathrm{C}$, however that anneal was needed to form the superconductor. This is indicated in Figure 3, which shows the normalized resistance-temperature $(R-T)$ characteristic of two films similar to the one in Figure 2. Both of these films have as deposited compositions of $\mathrm{Ba} / \mathrm{Y}=2.00$ and $\mathrm{Cu} / \mathrm{Y}=3.01$.

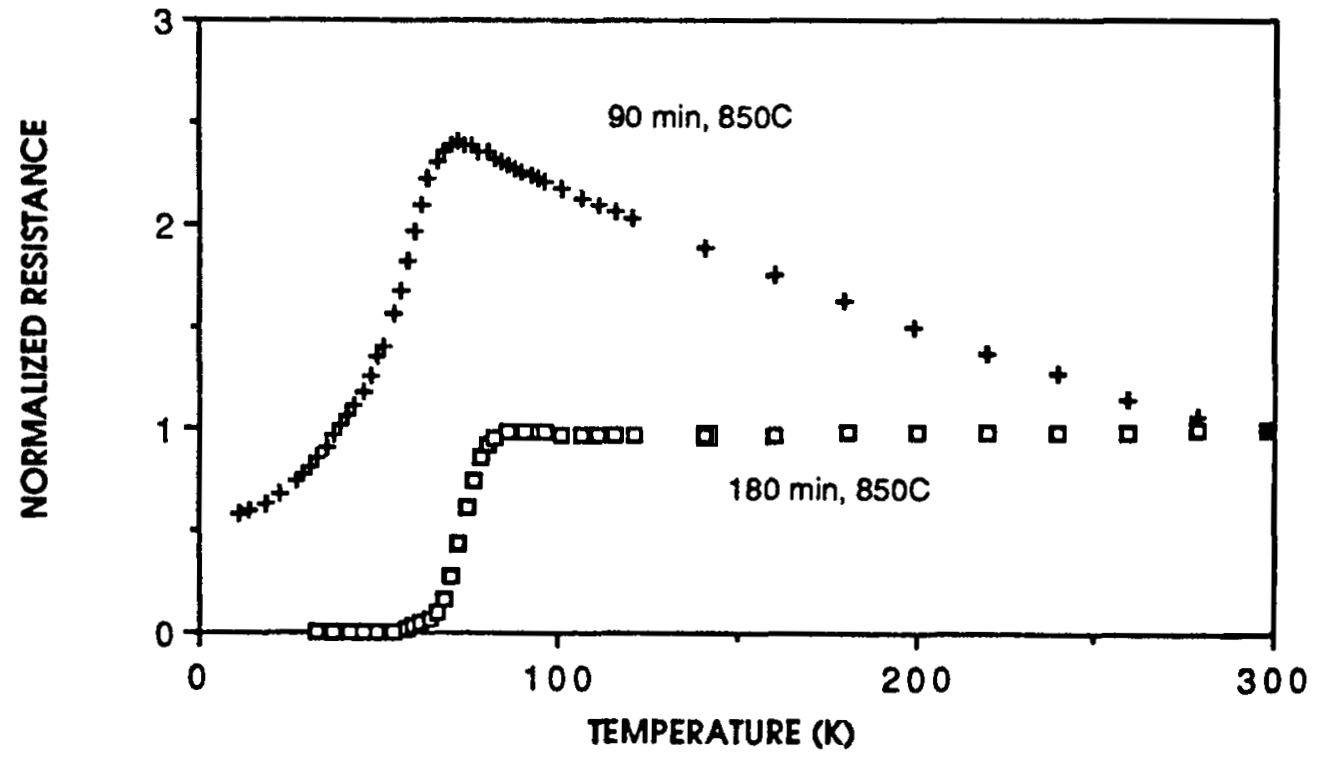

Figure 3: Normalized resistance as a function of temperature for two Y-Ba-Cu-O films on silicon with a $\mathrm{ZrO}_{2}$ buffer. 
They were annealed at $850^{\circ} \mathrm{C}$ for $90 \mathrm{~min}$ and $180 \mathrm{~min}$. The sample annealed for the shorter time has a semiconducting normal state characteristic and never achieved zero resistance. Its room temperature resistivity was also more than an order of magnitude larger than that of the sample annealed for $180 \mathrm{~min}$. We have tried shorter anneals at $950^{\circ} \mathrm{C}$, comparable to the procedure we use with $\mathrm{SrTiO}_{3}$ substrates", but they also produced poor films on silicon.

An Auger depth profile through a film deposited directly on a YSZ substrate is shown in Figure 4. This sample was annealed at $900^{\circ} \mathrm{C}$ for 45 min and produced a superconducting film. With the exception of the larger Ba concentration $(\mathrm{Ba} / \mathrm{Y}=2.3)$ this profile is very similar to that of the film with the thick $\mathrm{ZrO}_{2}$ buffer layer on silicon.

A six layer deposition with a pre-anneal thickness of approximately $0.6 \mu \mathrm{m}$ was performed onto several silicon samples with a $0.2 \mu \mathrm{m}$ buffer layer. There were two reasons for this deposition. The first was to check the utility of a thin $\mathrm{ZrO}_{2}$ buffer layer on silicon. The second was to reduce the sputtering time required to reach the interface and thereby decrease any artificial broadening of the interface due to the sputtering process. Three samples were annealed for 60,120 and $180 \mathrm{~min}$ at $850^{\circ} \mathrm{C}$. Upon removal of the samples from the furnace, it was apparent that extensive interaction had taken place between the film and the silicon as the film was not black and resembled a film deposited directly an silicon. The Auger profiles through the $60 \mathrm{~min}$ annealed and $120 \mathrm{~min}$ annealed films are shown in Figures 5 and 6 respectively. Neither the film/buffer or buffer/substrate interfaces are well defined. There appears to have been considerable interaction among all of the constituents of the film, buffer layer and substrate. In particular, barium is present in large amounts throughout the buffer layer and into the silicon, silicon is present throughout the buffer layer and appears to have accumulated at the surface of the film and zirconia extends through the film and into the substrate. Copper and yttrium both have long tails into the buffer layer for the $60 \mathrm{~min}$ sample and copper extends through the buffer layer and has accumulated at the silicon surface for the $120 \mathrm{~min}$ sample.

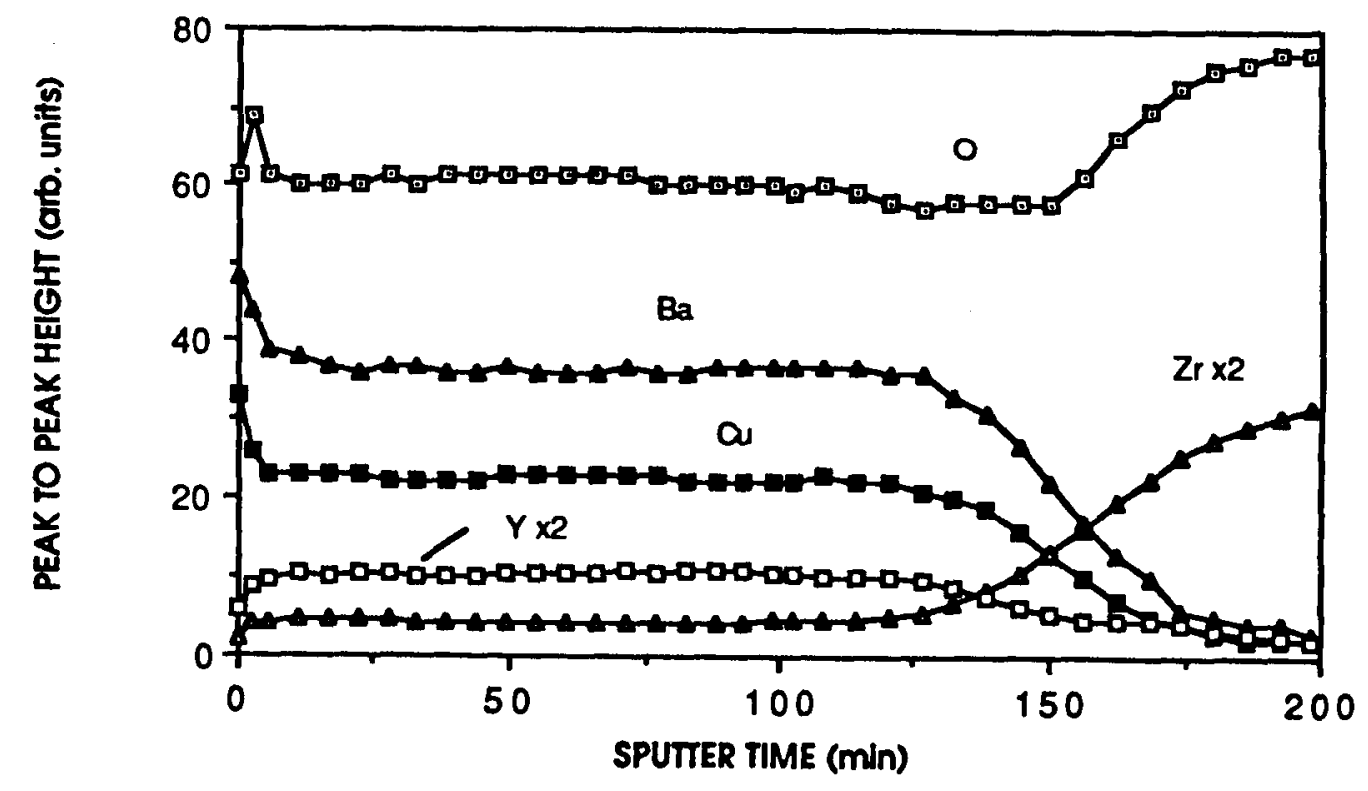

Figure 4: Auger depth profile through a Y-Ba-Cu-O film on a YSZ substrate. 


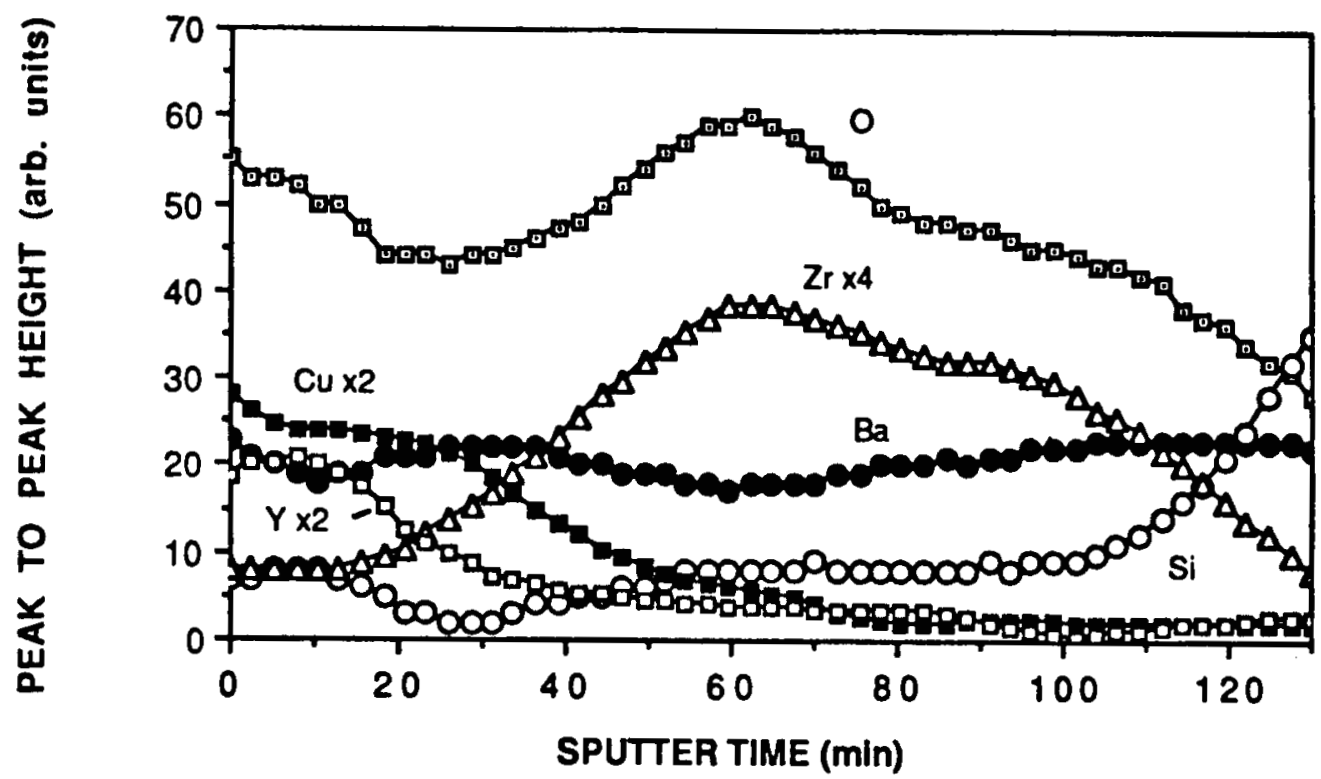

Figure 5: Auger depth profile through a $\mathrm{Y}-\mathrm{Ba}-\mathrm{Cu}-\mathrm{O}$ film on silicon with a $0.2 \mu \mathrm{m}$ buffer layer. Annealed $60 \mathrm{~min}$ at $850^{\circ} \mathrm{C}$.

The same deposition, with $0.2 \mu \mathrm{m} \mathrm{zrO}_{2}$ buffer layer, was performed onto three sapphire substrates. They were also annealed for 60,120 and $180 \mathrm{~min}$ at $850^{\circ} \mathrm{C}$. These samples were shiny, smooth and black when removed from the furnace. Silver contacts were formed on the samples and their R-T characteristics were measured. They are plotted in Figure 7 . There is a clear improvement in the normal state characteristic and in the superconducting transition with increasing annealing time, however, unlike the case for silicon, even the sample annealed for $60 \mathrm{~min}$ became a superconductor.

Auger profiles for the samples annealed for $60 \mathrm{~min}$ and $180 \mathrm{~min}$ are shown in Figures 8 and 9 respectively. These superconducting films are not as uniform as the thicker films on the thicker buffer layer, but they are

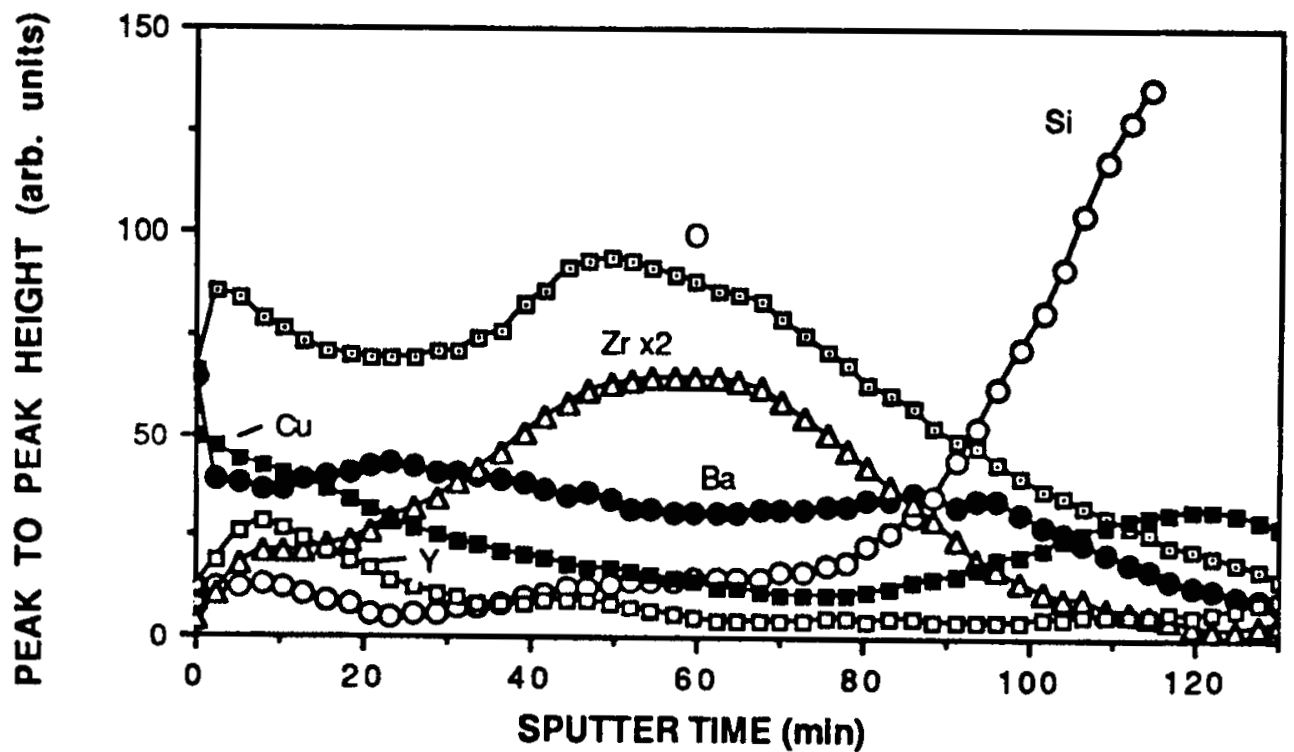

Figure 6: Auger depth profile through a $\mathrm{Y}-\mathrm{Ba}-\mathrm{Cu}-\mathrm{O}$ film on silicon with a $0.2 \mu \mathrm{m}$ buffer layer. Annealed $120 \mathrm{~min}$ at $850^{\circ} \mathrm{C}$. 


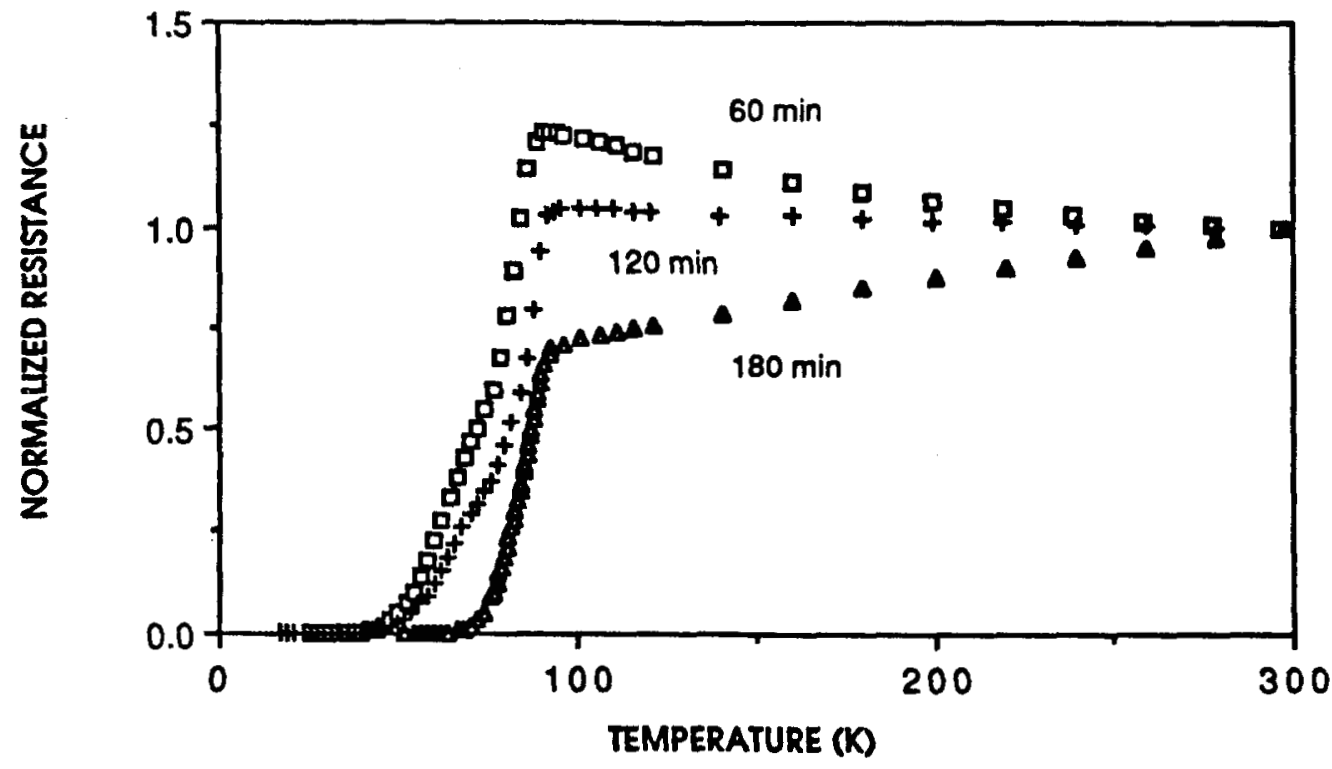

Figure 7: Normalized resistance as a function of temperature for three Y-Ba-Cu-O films on sapphire with a $0.2 \mu \mathrm{m}$ buffer layer.

greatly better than the films on silicon with the same thickness buffer layer. The interfaces on both sides of the buffer layer are reasonably well defined. There is significant penetration of barium into the buffer layer but it appears no worse for the $180 \mathrm{~min}$ film than for the $60 \mathrm{~min}$ film. Copper and yttrium also have tails into the buffer layer but they too are no worse with the longer anneal. The aluminum tail into the buffer layer may be an artifact due to the proximity of the barium and aluminum peaks in the Auger spectrum.

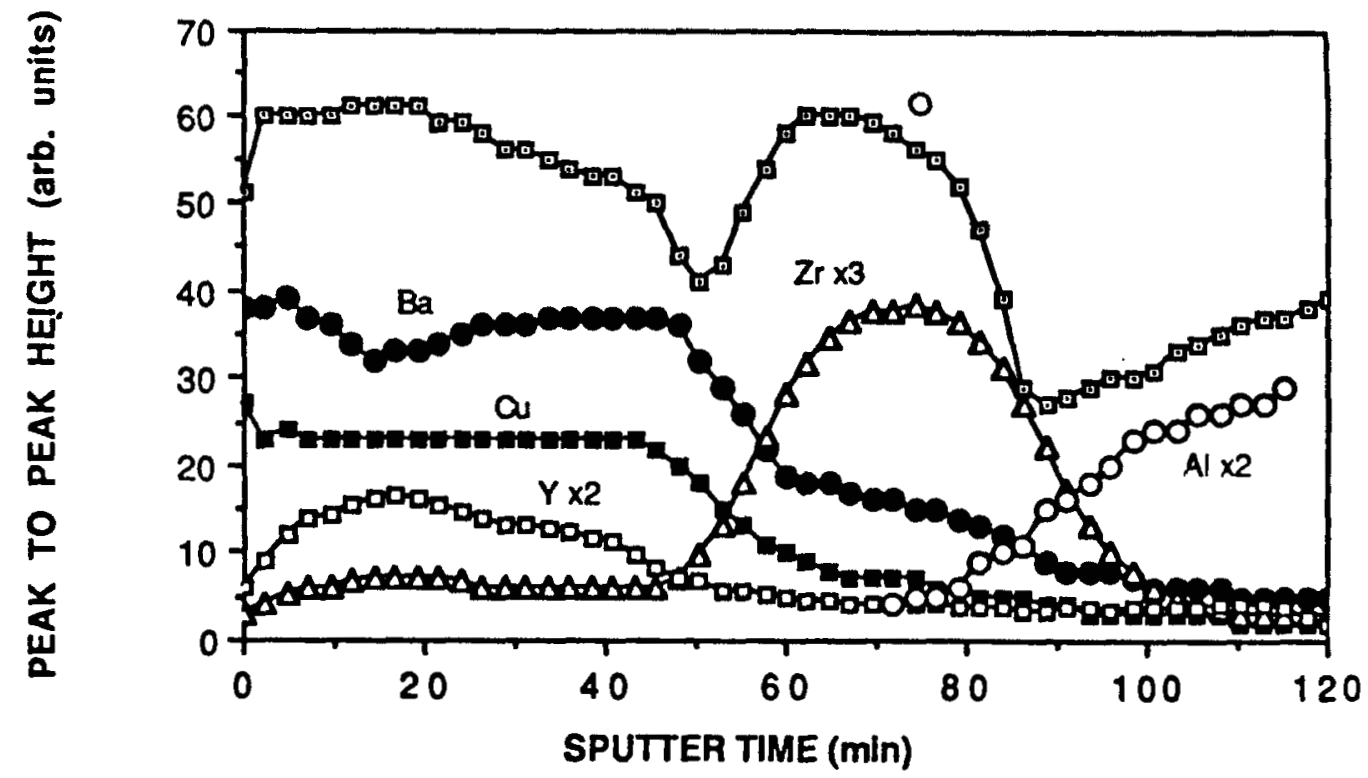

Figure 8: Auger depth profile through a Y-Ba-Cu-O film on sapphire with a $0.2 \mu \mathrm{m}$ buffer layer. Annealed $60 \mathrm{~min}$ at $850^{\circ} \mathrm{C}$ 


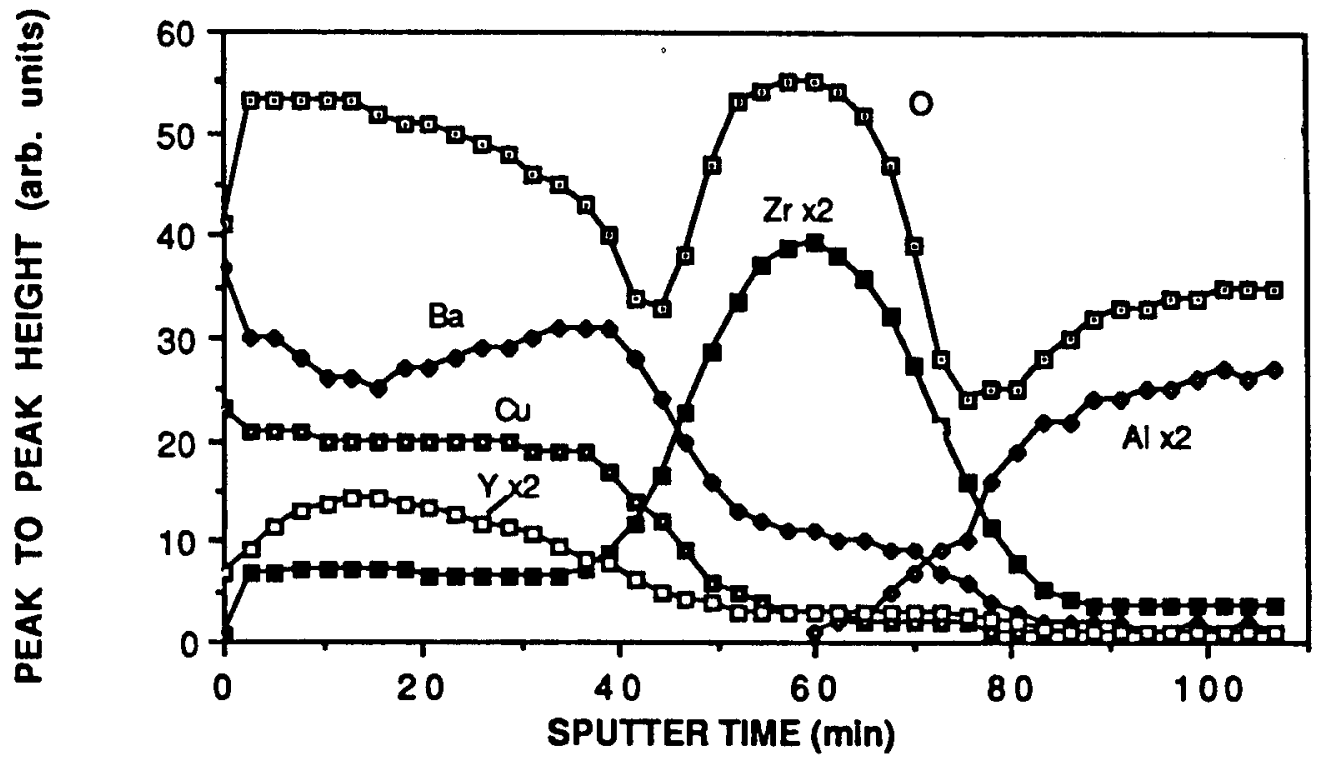

Figure 9: Auger depth profile through a Y-Ba-Cu-O film on sapphire with a $0.2 \mu \mathrm{m}$ buffer layer. Annealed $180 \mathrm{~min}$ at $850^{\circ} \mathrm{C}$.

Figure 10 shows the resistance temperature characteristic of a $\mathrm{YBa}_{2} \mathrm{Cu}_{3} \mathrm{O}_{7-8}$ film on $\mathrm{SrTiO}_{3}$. This film was deposited with a $\mathrm{Ba} / \mathrm{Y}$ ratio of 2.25 and a Cu $/ Y$ ratio of 3.01 and was annealed at $900^{\circ} \mathrm{C}$ for $45 \mathrm{~min}$. The onset temperature was $93 \mathrm{~K}$, the 908 to 108 transition width was $3.6 \mathrm{~K}$ and the critical temperature was $85 \mathrm{~K}$. The transition temperature was found to degrade only slightly over a period of one month. In earlier work" we

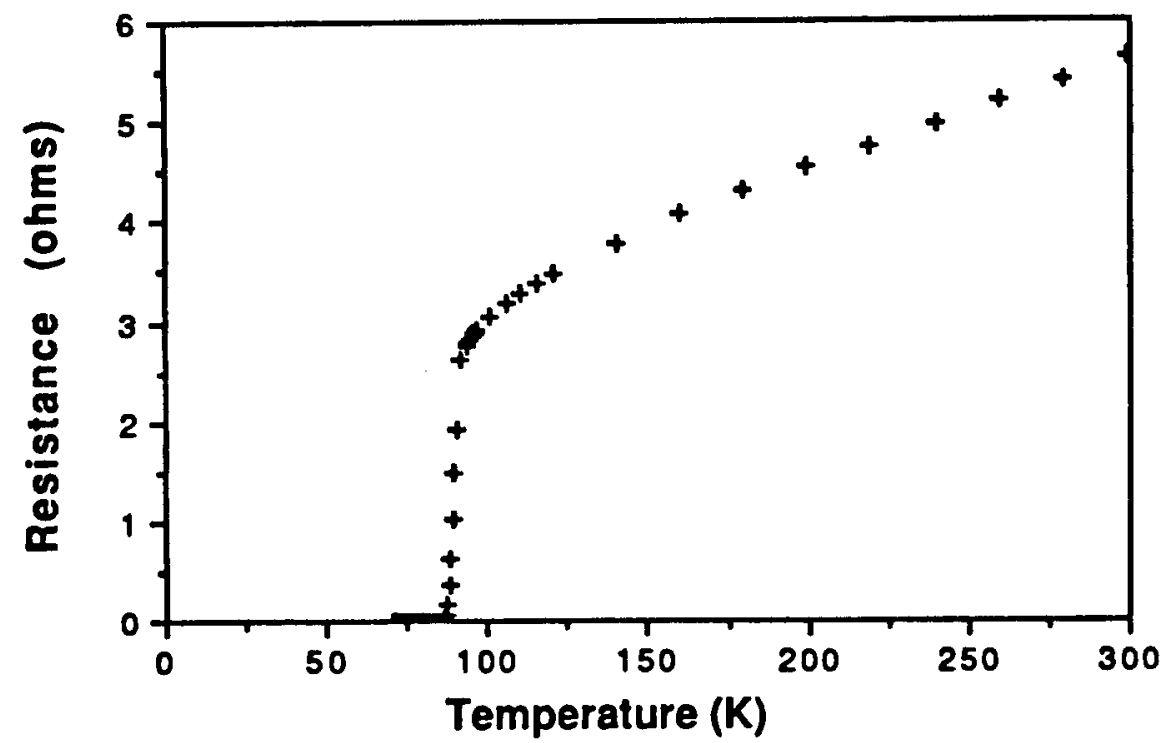

Figure 10: Resistance as a function of temperature for a Y-Ba-Cu-O film on $\mathrm{SrTiO}_{3}$. 
reported that for films on $\mathrm{SrTiO}_{3}$, low $\mathrm{Ba} / \mathrm{Y}$ ratios resulted in normal state resistance-temperature characteristics with a negative slope while films with $\mathrm{Ba} / \mathrm{Y}$ greater than about 2.2 had metallic normal state characteristics. While we have not performed as thorough an investigation into the dependence on composition of the superconducting transition for silicon and sapphire substrates, the data we currently have show different behavior. For both silicon and sapphire substrates, when the film is annealer at $850^{\circ} \mathrm{C}$ for $180 \mathrm{~min}$, the normal state resistance is metallic for lower $\mathrm{Ba} / \mathrm{Y}$ ratios and tends to become more like a semiconductor as the Ba/ $Y$ ratio is increased. In addition, the as deposited compositions which produce the better critical temperatures appear to have significantly lower $\mathrm{Ba} / \mathrm{I}$ ratios than for films on $\mathrm{SrTiO}_{3}$.

\section{SUMMARY AND CONCLUSIONS}

Multi-layer sequential evaporation of $\mathrm{BaF}_{2}, \mathrm{Y}$, and $\mathrm{Cu}$ layers has been employed for the formation of $\mathrm{Y}-\mathrm{Ba}-\mathrm{Cu}-\mathrm{O}$ thin films. Auger electron spectroscopic depth profiles have been used to study the films formed on silicon and sapphire substrates coated with $\mathrm{ZrO}_{2}$ buffer layers.

Films that were uniform throughout their thickness were formed on silicon when a thick buffer layer was used. The interface was broad but well defined and since the film and buffer layer were thick, a superconducting film could be formed with a $180 \mathrm{~min}$ anneal at $850^{\circ} \mathrm{C}$. For the $0.2 \mu \mathrm{m}$ buffer layers on silicon, a $60 \mathrm{~min}$ anneal was sufficient to cause drastic intermixing of the constituents of the film, buffer layer and silicon. This intermixing proceeded to become worse for longer anneals.

The $0.2 \mu \mathrm{m} \mathrm{ZrO}_{2}$ buffer layers on sapphire, on the other hand, were sufficient to protect the superconductor from the substrate. Although the Auger depth profiles showed a significant amount of barium in the films, superconductivity was achieved for 60,120 and $180 \mathrm{~min}$ anneals at $850^{\circ} \mathrm{C}$. The amount of intermixing did not appear to become worse for the longer anneals and the electrical properties of the films improved.

The data generated during these investigations also suggest that the optimal as deposited composition for multi-layer formation of superconducting films on silicon and sapphire is different from that on $\mathrm{SrTiO}_{3}$. Further investigations into this are being undertaken.

\section{ACRNOWLEDGEMENTS}

This research is supported by the National Aeronautics and Space Administration, Lewis Research Center under cooperative research agreement NCC 3-105.

\section{REFERENCES}

1. M. Gurvitch and A. T. Fiory, Preparation and Substrate Reactions of Superconducting Y-Ba-Cu-O Films, Appl. Phys. Lett. 51, 1027 (1987).

2. A. Mogro-Campero and L. G. Turner, Thin Films of $\mathrm{Y}-\mathrm{Ba}-\mathrm{Cu}-\mathrm{O}$ on Silicon and Silicon Dioxide, Appl. Phys. Lett. 52, 1185 (1988).

3. K. Harada, N. Fujimori and S. Yazu, Y-Ba-Cu-O Thin Films on Si Substrate, Jpn. J. Appl. Phys. 27, L1524 (1988).

4. B-Y. Tsaur, M. S. Dilorio and A. J. Strauss, Preparation of Superconducting $\mathrm{YBa}_{2} \mathrm{Cu}_{3} \mathrm{O}_{x}$ Thin Films by Oxygen Annealing of Multilayer Metal Films, Appl. Phys. Lett. 51, 858 (1987). 
5. C. X. Qiu and I. Shih, Y-Ba-Cu-O Thin Films Prepared by a Multilayer Vacuum Method, Appl. Phys. Lett. 52, 587 (1988).

6. C-A. Chang, C. C. Tsuei, C. C. Chi and T. R. McGuire, Thin Film YBaCuO Superconductors Formed by $\mathrm{Cu} / \mathrm{BaO} / \mathrm{X}_{2} \mathrm{O}_{3}$ Layer Structures, Appl. Phys. Lett. 52, 72 (1988).

7. Z. L. Bao, F. R. Wang, Q. D. Jiang, S. Z. Wang, Z. Y. Ye, R. Wu, C. Y. Li and D. L. Yin, YBaCuO Superconducting Thin Films with zero Resistance at $84 \mathrm{~K}$ by Multilayer Deposition, Appl. Phys. Lett. 51, 946 (1987).

8. G. J. Valco, N. J. Rohrer, J. D. Warner and K. B. Bhasin, Sequentially Evaporated Thin Y-Ba-Cu-O Superconductor Films: Composition and Prucessing Effects, American Institute of Physics Conference Proceedings, to be published.

9. N. Hess, L. R. Tessler, U. Dai and G. Deutscher, Preparation and Patterning of YBaCuo Thin Films Obtained by Sequential Deposition of $\mathrm{CuO}_{\mathrm{x}} / \mathrm{Y}_{2} \mathrm{O}_{3} / \mathrm{BaF}_{2}$, Appl. Phys. Lett. 53, 698 (1988). 


\section{Report Documentation Page}

1. Report No.

2. Government Accession No.

3. Recipient's Catalog No

NASA TM-101432

4. Title and Subtitle

Characterization of $\mathrm{ZrO}_{2}$ Buffer Layers for Sequentially Evaporated

$\mathrm{Y}-\mathrm{Ba}-\mathrm{Cu}-\mathrm{O}$ on $\mathrm{Si}$ and $\mathrm{Al}_{2} \mathrm{O}_{3}$ Substrates

5. Report Date

7. Author(s)

George J. Valco, Norman J. Rohrer, John J. Pouch, Joseph D. Warner, and Kul B. Bhasin

9. Performing Organization Name and Address

National Aeronautics and Space Administration

Lewis Research Center

Cleveland, Ohio 44135-3191

12. Sponsoring Agency Name and Address

National Aeronautics and Space Administration

Washington, D.C. 20546-0001

Performing Organization Code

8. Performing Organization Report No.

E-4536

10. Work Unit No.

$307-51-00$

11. Contract or Grant No.

13. Type of Report and Period Covered

Technical Memorandum

14. Sponsoring Agency Code

15. Supplementary Notes

Prepared for the Conference on Science and Technology of Thin Film Superconductors cosponsored by the U.S. Department of Energy, Solar Energy Research Institute, National Bureau of Standards, Naval Research Laboratory, and Lawrence Berkeley Laboratory, Colorado Springs, Colorado, November 14-18, 1988. George J. Valco and Norman J. Rohrer, Department of Electrical Engineering, The Ohio State University, Columbus, Ohio 43210; John J. Pouch, Joseph D. Warner, and Kul B. Bhasin, NASA Lewis Research Center.

16. Abstract

Thin film high temperature superconductors have the potential to impact the microwave technology for space communications systems. For such applications it is desirable that the films be formed on substrates such as $\mathrm{Al}_{2} \mathrm{O}_{3}$ which have good microwave properties. We have investigated the use of $\mathrm{ZrO}_{2}$ buffer layers between $\mathrm{Y}-\mathrm{Ba}-\mathrm{Cu}-\mathrm{O}$ and the substrate. Our superconducting films have been formed by multi-layer sequential electron beam evaporation of $\mathrm{Cu}, \mathrm{BaF}_{2}$ and $\mathrm{Y}$ with subsequent annealing. The three layer sequence of $\mathrm{Y} / \mathrm{BaF}_{2} / \mathrm{Cu}$ is repeated four times for a total of twelve layers. Such a multi-layer film, approximately $1 \mu \mathrm{m}$ thick, deposited directly on $\mathrm{SrTiO}_{3}$ and annealed at $900{ }^{\circ} \mathrm{C}$ for $45 \mathrm{~min}$ produces a film with a superconducting onset of $93 \mathrm{~K}$ and critical temperature of $85 \mathrm{~K}$. Auger electron spectroscopy in conjunction with argon ion sputtering was used to obtain the distribution of each element as a function of depth for an unannealed film, the annealed film on $\mathrm{SrTiO}_{3}$ and annealed films on $\mathrm{ZrO}_{2}$ buffer layers. The individual layers were apparent. After annealing, the bulk of the film on $\mathrm{SrTiO}_{3}$ is observed to be fairly uniform while films on the substrates with buffer layers are less uniform. The $\mathrm{Y}-\mathrm{Ba}-\mathrm{Cu}-\mathrm{O} / \mathrm{ZrO} \mathrm{O}_{2}$ interface is broad with a long $\mathrm{Ba}$ tail into the $\mathrm{ZrO}_{2}$, suggesting interaction between the film and the buffer layer. The underlying $\mathrm{ZrO}_{2} / \mathrm{Si}$ interface is sharper. The detailed Auger results for these films are presented and compared with samples annealed at different temperatures and durations.

17. Key Words (Suggested by Author(s))

High temperature superconductors; Thin films; Microwave substrates; Electron beams;

Mixed oxides
18. Distribution Statement

Unclassified - Unlimited

Subject Category 33 